\title{
PENGARUH PELATIHAN GAYA KEPEMIMPINAN DAN DISIPLIN KERJA TERHADAP KINERJA KARYAWAN PT. PERKEBUNAN NUSANTARA XIV (PERSERO) MAKASSAR
}

\author{
Nur Rahmi \\ Manajemen, Universitas Ichsan Gorontalo \\ Email: nurrahmirahim77@gmail.com
}

\begin{abstract}
Diterima: 2 Februari 2019; direvisi: 10 Maret 2019; dipublikasikan: 09 April 2019
(C)2019 -Bongaya Journal for Research in Management STIEM Bongaya. Ini adalah artikel dengan akses terbuka dibawah licenci CC BY-NC-4.0 (https://creativecommons.org/licenses/by-nc/4.0/ ).
\end{abstract}

\begin{abstract}
This explanatory research tried to explain influence and causality relationship between variables training, leadership style, and work discipline to the performance of employees. The samples used for data collection in this study amounted to 134 employees and using by the simple random sampling technique. Analysis technique used in this research is analysis of multiple regression ( multiple regression).The result showed that the training, the leadership style and work discipline simultaneously partially and simultaneously has a positive impact significantly to performance of employee. The determination showed $\left(R^{2}\right)$ 0,996 or that is equal 99,6\%. Employee performance. Training, leadership he style and work dicipline also in partially has a positive impact significantly to performance of employee. The study it can be seen that the most dominant variable exacted on employee,s performance is work dicipline.
\end{abstract}

Keywords: Training; Leadership Style, Work Dicipline, Performance of Employee

Abstrak: Penelitian ini termasuk kedalam penelitian eksplanasi (explanatory research) yang bertujuan menjelaskan pengaruh dan hubungan kausalitas antara variabel pelatihan, gaya kepemimpinan, dan disiplin kerja terhadap kinerja karyawan. Jumlah sampel dalam penelitian sebanyak 134 orang karyawan. Pengambilan sampel dilakukan menggunakan tekhnik Simple Random Sampling (probability sampling). Data penelitian dianalisis mnggunakan analisis regresi berganda (multiple regression). Dari hasil penelitian terlihat bahwa pelatihan, gaya kepemimpinan dan disiplin kerja secara simultan berpengaruh positif signifikan terhadap kinerja karyawan. Koefisien determinasi $\left(\mathrm{R}^{2}\right)$ menunjukkan angka sebesar 0,996 atau 99,6\%. Ini berati bahwa semua variabel independen yang diteliti yaitu Pelatihan,Gaya Kepemimpinan dan Disiplin Kerja secara simultan atau secara serempak mampu menjelaskan hubungan Kinerja Karyawan. Secara parsial pelatihan juga terbukti berpengaruh terhadap kinerja karyawan, gaya kepemimpinan juga secara parsial berpengaruh positif signifikan terhadap kinerja karyawan. Begitu pula dengan disiplin kerja ternyata secara parsial berpengaruh terhadap kinerja karyawan. Diantara ketiga variabel bebas yang diteliti, terlihat bahwa variabel yang paling dominan pengaruhnya terhadap kinerja karyawan adalah gaya kepemimpinan.

Katakunci: Pelatihan, Gaya Kepemimpinan, Disiplin Kerja, Kinerja Karyawan 


\section{PENDAHULUAN}

Kualitas sumber daya manusia ditentukan oleh sejauh mana sistem dalam bidang sumber daya manusia ini sanggup menunjang dan memuaskan keinginan karyawan maupun perusahaan. Peningkatan pengetahuan, skill, perubahan sikap, perilaku, koreksi terhadap kekurangan-kekurangan kinerja dibutuhkan untuk meningkatkan kinerja dan produktivitas melalui pelatihan dan motivasi dari pimpinan atau perusahaan. Pelatihan akan memberikan kesempatan bagi karyawan mengembangkan keahlian dan kemampuan baru dalam bekerja agar apa yang diketahui dan dikuasai saat ini maupun untuk masa mendatang dapat membantu karyawan untuk mengerti apa yang seharusnya dikerjakan dan mengapa harus dikerjakan, memberikan kesempatan untuk menambah pengetahuan dan keahlian yang dimiliknya.

Pelatihan adalah suatu kegiatan untuk memperbaiki kemampuan kerja seseorang dalam kaitannya dengan aktivitas ekonomi. Pelatihan membantu karyawan dalam memahami suatu pengetahuan praktis dan penerapannya, guna meningkatkan keterampilan, kecakapan, dan sikap yang diperlukan organisasi dalam usaha mencapai tujuan organisasi.

Payaman Simanjuntak (2005), berpendapat bahwa pelatihan adalah proses belajar mengajar dengan menggunakan teknik dan metode tertentu secara konsepsional dapat dikatakan bahwa latihan dimaksudkan untuk meningkatkan keterampilan dan kemampuan kerja seseorang atau sekelompok orang. Biasanya yang sudah bekerja pada suatu organisasi yang efisiensi, efektivitas dan produktivitas kerjanya dirasakan perlu untuk dapat ditingkatkan secara terarah dan pragmatik

Pelaksanaan pelatihan dimaksudkan untuk mendapatkan tenaga kerja yang memiliki pengetahuan, keterampilan yang baik, kemampuan dan sikap yang baik untuk mengisi jabatan pekerjaan yang tersedia dengan produktivitas kerja yang tinggi, yang mampu menghasilkan hasil kerja yang baik. Kebutuhan untuk setiap pekerja sangat beragam, untuk itu pelatihan perlu dipersiapkan dan dilaksanakan sesuai dengan bidang pekerjaannya, dengan demikian pekerjaan yang dihadapi akan dapat dikerjakan dengan lancar sesuai dengan prosedur.
Terkait dengan pelatihan, Gary Dessler (2009) mengemukakan bahwa pelatihan merupakan proses mengajarkan karyawan baru atau yang ada sekarang, keterampilan dasar yang mereka butuhkan untuk menjalankan pekerjaan mereka". Pelatihan merupakan salah satu usaha dalam meningkatkan mutu sumber daya manusia dalam dunia kerja. Karyawan, baik yang baru ataupun yang sudah bekerja perlu mengikuti pelatihan karena adanya tuntutan pekerjaan yang dapat berubah akibat perubahan lingkungan kerja, strategi, dan lain sebagainya.

Berkaitan dengan kebutuhan pelatihan tersebut, maka harus diketahui pengetahuan dan keterampilan apa saja yang dibutuhkan karyawan untuk bekerja dan pengetahuan serta keterampilan apa saja yang telah dimiliki karyawan. Selanjutnya, Dale (2003: 35), mengatakan bahwa pengetahuan yang dimiliki oleh seseorang bisa dikategorikan dalam dua jenis, yaitu: pengetahuan yang disadari, dan pengetahuan yang tidak disadari.

Pelatihan bagi karyawan merupakan sebuah proses mengajarkan pengetahuan dan keahlian tertentu serta sikap agar karyawan semakin terampil dan mampu melaksanakan tanggung jawabnya dengan semakin baik. Sesuai dengan standar. Biasanya pelatihan merujuk pada pengembangan keterampilan bekerja yang dapat digunakan segera.

Disamping masalah pelatihan, persoalan kinerja karyawan juga hampir selalu dikaitkan dengan gaya kepemimpinan yang diterapkan dalam sebuah organisasi. Penelusuran literatur terkait dengan praktek organisasional menunjukkan bahwa gaya kepemimpinan merupakan salah satu faktor yang juga merupakan penentu kinerja karyawan.

Kepemimpinan atau leadership merupakan ilmu terapan dari ilmu-ilmu sosial, sebab prinsip prinsip dan rumusan-rumusannya bermanfaat dalam meningkatkan kesejahteraan manusia.

Arep \& Tanjung ( 2002:235) menerangkan bahwa "Kepemimpinan adalah kemampuan seseorang untuk menguasai atau mempengaruhi orang lain atau masyarakat yang saling berbeda-beda menuju kepada pencapaiaan tujuan tertentu "

Robbins (2006:432) mendefenisikan kepemimpinan sebagai kemampuan untuk mempengaruhi kelompok menuju pencapaian sasaran.

Kartono (2005:153) mengemukakan kepemimpinan adalah kemampuan untuk memberikan pengaruh yang konstruktif kepada 
orang lain untuk melakukan suatu usaha kooperatif mencapai tujuan yang sudah di rencanakan.

Kepemimpinan yang efektif dihasilkan oleh pemimpin yang menerapkan gaya kepemimpinan yang efektif pula. Sementara itu, pendapat lain menyebutkan bahwa gaya kepemimpinan adalah pola tingkah laku (katakata dan tindakan-tindakan) dari seorang pemimpin yang dirasakan oleh orang lain (Hersey, 2004:29).

Gaya kepemimpinan adalah perilaku atau cara yang dipilih dan dipergunakan pemimpin dalam mempengaruhi pikiran, perasaan, sikap dan perilaku para anggota organisasi bawahannya (Nawawi, 2003:115).

Gaya kepemimpinan yang baik adalah gaya kepemimpinan yang dapat memberikan motivasi kerja pada bawahannya. Widyatmini dan Hakim (2008:169) mengatakan seorang pemimpin harus melakukan berbagai keahlian, pengalaman, kepribadian dan motivasi setiap individu yang di pimpinnya.

Selain faktor pelatihan dan gaya kepemimpinan seperti yang dijelaskan diatas, faktor lain yang juga berpengaruh terhadap kinerja karyawan adalah disiplin kerja karyawan.

Pendapat Toni Listianto dan Bambang Setiaji (2005) mengatakan bahwa salah satu faktor yang berpengaruh terhadap kinerja adalah disiplin kerja karyawan. Kedisiplinan adalah prosedur yang mengoreksi atau menghukum bawahan karena melanggar peraturan atau prosedur. Disiplin kerja merupakan bentuk pengendalian diri karyawan dan pelaksanaan yang teratur dan menunjukan tingkat kesungguhan tim kerja di dalam sebuah organisasi. Tindakan disiplin yang efektif terpusat pada perilaku karyawan yang salah, tidak pada karyawan sebagai pribadi (Henry Simamora, 1997).

Sementara itu, pendapat Malayu (2003) bahwa disiplin kerja adalah fungsi operatif dari manajemen sumber daya manusia yang terpenting karena semakin baik disiplin karyawan, semakin tinggi kinerja kerja yang dapat dicapai seorang karyawan. Tanpa disiplin kerja karyawan yang baik, sulit bagi organisasi perusahaan mencapai hasil yang optimal.. Hal ini mendorong gairah kerja, semangat kerja, dan terwujudnya tujuan perusahaan, karyawan, dan masyarakat. Oleh karena itu, setiap manajer selalu berusaha agar para bawahannya mempunyai disiplin yang baik. Seorang manajer dikatakan efektif dalam kepemimpinannya,jika para bawahannya berdisiplin baik. Untuk memelihara dan meningkatkan kedisiplinan yang baik adalah hal yang sulit, karena banyak faktor yang mempengaruhinya. Seseorang akan bersedia mematuhi semua peraturan serta melaksanakan tugas-tugasnya, baik secara sukarela maupun karena terpaksa. Disiplin kerja diartikan jika karyawan selalu datang dan pulang tepat pada waktunya, mengerjakan semua pekerjaannya dengan baik, mematuhi semua peraturan perusahaan dan norma-norma sosial yang berlaku.

\section{Hipotesis}

Penelitian ini menguji hipotesis mengenai hubungan dan pengaruh antara Pelatihan, Gaya Kepemimpinan, Disiplin Kerja terhadap Kinerja Karyawan :

1. Pelatihan berpengaruh terhadap Kinerja Karyawan.

2. Gaya kepemimpinan berpengaruh terhadap Kinerja Karyawan.

3. Disiplin Kerja berpengaruh terhadap kinerja karyawan

\section{METODE}

\section{Analisis Deskriptif}

Penelitian ini dilakukan untuk menguji hubungan kausal antar variabel Pelatihan, Gaya Kepemimpinan dan Disiplin Kerja terhadap Kinerja Karyawan. Data yang terkumpul kemudian dianalisis dengan menggunakan analisis deskriptif dan analisis inferensial. Analisis deskriptif digunakan untuk memperoleh gambaran variabel terikat yaitu kinerja karyawan dan variabel bebas yaitu Pelatihan, Gaya Kepemimpinan dan Disiplin Kerja.

\section{Analisis Regresi Berganda (Multiple Regression Analysis)}

Analisis regresi yang diterapkan dalam penelitian ini adalah regresi berganda untuk memeriksa dan memodelkan hubungan antara variabel-variabel, serta mencari ada tidaknya pengaruh variabel bebas dari masing-masing tinjauan terhadp variabel terikat, dan mengukur seberapa besar pengaruhnya. Disebut berganda karena variabel bebas pada penelitian ini terdiri lebih dari satu variabel bebas.

Analisis regresi berganda adalah metode analisis multivariate yang digunakan untuk mengetahui hubungan antara beberapa variabel independent dengan variabel dependen. Sehingga dalam penelitian ini analisis regresi berganda dilakukan untuk mengetahui hubungan antara 
variabel bebas yaitu pelatihan, Gaya Kepemimpinan dan Disiplin Kerja dengan variabel terikat (dependent) yakni Kinerja Karyawan.

Analisis dilakukan untuk mengetahui pengaruh antara variabel independen dengan variabel dependen, baik secara parsial maupun secara simultan. Analisis regresi juga dilakukan pada tingkat $95 \%(\square=0,05)$ dan menggunakan metode enter yaitu semua variabel independen dimasukkan secara bersama dalam model perhitungan, kemudian melihat nilai $\mathrm{t}$ hitung untuk dibandingkan dengan angka kritis pada tabel $\mathrm{t}$ atau dengan melihat tingkat signifikannya dengan nilai $\square=0,05$.

Model regresi untuk Kinerja Karyawan adalah Analisis persamaan regresi linear berganda :

$$
Y=b 0+b 1 \times 1+b 2 \times 2+b 3 \times 3+e
$$

Keterangan :

$$
\begin{array}{llll}
\mathrm{Y} & = & \text { Kinerja Karyawan } & \\
\mathrm{X} 1 & = & \text { Pelatihan } & \\
\mathrm{X} 2 & = & \text { Gaya Kepemimpinan } & \\
\mathrm{X} 3 & \text { Disiplin Kerja } & \\
\mathrm{b}_{0} & =\text { Konstanta } & & \\
\mathrm{b}_{1}, \mathrm{~b}_{2}, \mathrm{~b}_{3} & = & \text { Koefisien regresi } & \text { masing } \\
& \text { hubungan antara } & \text { variabel } \\
& & \text { dependen dan } & \text { variabel } \\
& \text { independen } & & \\
\mathrm{e} & = & \text { Faktor pengganggu } &
\end{array}
$$

\section{Variabel Penelitian dan Definisi Operasional}

Dalam penelitian ini pengukuran data dilakukan menggunakan skala likert. Skala likert ini digunakan untuk mengukur sikap, pendapat dan persepsi responden terhadap obyek (Sekaran, 2003). Upaya ini dilakukan untuk menyamakan persepsi dalam menginterpretasikan makna variabel-variabel yang digunakan dan dapat diukur. sehubungan dengan itu maka dalam penelitian in dikemukakan variabel dan defenisi operasional sebagai berikut:

\section{Pelatihan (X1)}

Adalah suatu kegiatan untuk memperbaiki kemampuan kerja karyawan dalam kaitannya dengan aktivitas ekonomi yang dapat membantu karyawan dalam memahami suatu pengetahuan praktis dan penerapannya guna meningkatkan keterampilan, kecakapan dan sikap yang diperlukan organisasi dalam mencapai tujuan yang juga disesuaikan dengan tuntutan pekerjaan yang akan diemban oleh seorang karyawan serta sangat berpengaruh terhadap peningkatan kinerja karyawan dalam suatu perusahaan.

\section{Dimensi dan Indikator Pelatihan}

(Mangkunegara, 2011) menguraikan beberapa dimensi dan indikator dalam pelatihan seperti yang akan dijelaskan sebagai berikut:

1. Instruktur

a. Pendidikan; Pendidikan lebih diarahkan pada peningkatan kemampuan (ability) seseorang (instruktur) melalui jalur formal dengan jangka waktu yang panjang, tujuannya untuk memaksimalkan penyampaian materi kepada peserta pelatihan.

b. Penguasaan materi; Penguasaan materi oleh seorang instruktur merupakan hal yang sangat penting agar dapat melakukan proses pelatihan dengan baik, dengan demikian diharapkan para peserta pelatihan mampu memahami materi yang disampaikan.

2. Peserta

a. Semangat mengikuti pelatihan; Hal ini merupakan salah satu faktor yang menentukan lancar dan berhasilnya proses pelatihan. Jika instruktur bersemangat dalam memberikan materi pelatihan maka peserta pelatihan juga pasti akan bersemangat mengikuti program pelatihan tersebut, begitupun sebaliknya.

b. Seleksi; Sebelum program pelatihan dilaksanakan, terlebih dahulu perusahaan melakukan proses seleksi, yaitu pemilihan sekelompok orang dalam perusahaan yang paling memenuhi kriteria untuk posisi yang tersedia di perusahaan.

\section{Materi}

a. Sesuai tujuan; Pemberian materi dalam program pelatihan kepada peserta pelatihan harus sesuai dengan tujuan pelatihan sumber daya manusia yang hendak dicapai oleh perusahaan.

b. Sesuai komponen peserta; Pemberian materi dalam program pelatihan akan lebih efektif bila disesuaikan dengan komponen peserta sehingga program pelatihan tersebut dapat menambah kemampuan peserta.

c. Penetapan sasaran; Pemberian materi kepada peserta harus tepat sasaran sehingga mampu mendorong peserta pelatihan untuk 
mengimplementasikannya dalam

pelaksanaan pekerjaan mereka dikantor.

4. Metode

a. Pensosialisasian tujuan; Metode penyampaian sesuai dengan materi yang hendak disampaikan, sehingga peserta pelatihan diharapkan dapat menangkap maksud serta tujuan yang disampaikan oleh instruktur.

b. Memiliki sasaran yang jelas; Agar menjamin berlangsungnya kegiatan pelatihan yang efektif $\mathrm{maka}$ p e 1 a t i h a $\mathrm{n} \mathrm{h}$ a r u s memiliki sasaran yang jelas yaitu menghasilkan pemahaman terhadap kebutuhan peserta pelatihan.

\section{Tujuan}

Meningkatkan keterampilan; Pelatihan yang diselenggarakan diharapkan berhasil meningkatkan skill/ keterampilan, pengetahuan dan tingkah laku peserta atau calon karyawan baru.

\section{Gaya Kepemimpinan (X2)}

Adalah kemampuan seseorang untuk menguasai atau mempengaruhi orang lain atau masyarakat yang saling berbeda-beda menuju kepada pencapaiaan tujuan tertentu.

\section{Dimensi dan Indikator Gaya Kepemimpinan}

Gaya Kepemimpinan dalam penelitian ini menggunakan tolok ukur gaya kepemimpinan tranformasional menurut (Robbins, 2010) yang mengusulkan empat dimensi kepemimpinan transformasional dalam kadar kepemimpinan seseorang, yaitu:

Adapun indikator yang digunakan dalam penelitian ini yaitu:

1) Dimensi pengaruh ideal (idealized influence) yang memiliki tiga indikator yakni: (a) Pemimpin sebagai panutan, (b) Sikap hormat dari bawahan, (c) Pemimpin memberikan kepercayaan kepada bawahan

2) Dimensi motivasi yang inspiratif (inspirational motivation) yang terdiri dari dua indikator yakni: (a) Inspirasi untuk menyelesaikan tugas, (b) Motivasi untuk menyelesaikan tugas dengan semangat.

3) Dimensi stimulasi intelektual (intellectual stimulation) yang terdiri dari atas indikator yakni: (a) Motivasi untuk inovatif, (b) Pemimpin mendorong bawahan untuk kreatif

4) Dimensi perhatian yang bersifat individual (individual consideration) yang memiliki dua indikator yakni: (a) Pertimbangan kebutuhan, (b) Pemberian perhatian.

\section{Disiplin Kerja (X3)}

Disiplin Kerja merupakan fungsi operatif dari manajemen sumber daya manusia yang tak kalah pentingnya karena semakin baik disiplin karyawan, semakin tinggi kinerja kerja yang dapat dicapai seorang karyawan. Tanpa disiplin karyawan yang baik, sulit bagi organisasi perusahaan mencapai hasil yang optimal.

\section{Dimensi dan Indikator Disiplin Kerja}

Banyak indikator tingkat kedisiplinan karyawan yang dijadikan acuan pada suatu organisasi. Menurut pandangan (Hasibuan, 2012) indikator Disiplin Kerja yaitu :

a. Tujuan kemampuan; Tujuan yang akan dicapai harus jelas dan ditetapkan secara ideal serta cukup menantang bagi kemampuan; karyawan.. Dimensi tujuan kemampuan diukur dapat melalui dua indikator yaitu : (a) Kehadiran pegawai tepat waktu di tempat kerja (b) Intensitas kehadiran pegawai selama bekerja

b. Tingkat kewaspadaan karyawan; Karyawan dalam pelaksanaan pekerjaannya selalu penuh perhitungan dan ketelitian akan memiliki tingkat kewaspadaan yang tinggi terhadap dirinya maupun pekerjaannya. Dimensi tingkat kewaspadaan diukur dengan menggunakan dua indikator yaitu : a. Kewaspadaan dan hati-hati dalam bekerja $b$. Menjaga dan merawat peralatan kerja

c. Ketaatan pada standar kerja: Dalam melaksanakan pekerjaannya karyawan diharuskan menaati semua standar kerja yang telah ditetapkan sesuai dengan aturan dan pedoman kerja agar kecelakaan kerja tidak terjadi atau dapat dihindari. Dimensi ketaatan pada standar kerja diukur dengan menggunakan tiga indikator yaitu : a. Memiliki rasa tanggung jawab dalam bekerja. b. Bekerja sesuai fungsi dan tugasnya. c. Bekerja sesuai jam kerja

d. Ketaatan pada peraturan kerja; Dimaksudkan demi kenyamanan dan kelancaran dalam bekerja. Dimensi ketaatan pada peraturan kerja diukur dengan dua indikator yaitu : a. Pemahaman pegawai atas peraturan kerja $b$. Menyelesaikan pekerjaan sesuai peraturan kerja 
e. Etika kerja; Diperlukan oleh setiap karyawan dalam melaksanakan perkerjaannya agar tercipta suasana harmonis, salin menghargai antar sesama karyawan. Dimensi etika kerja diukur dengan menggunakan satu indikator yaitu: Memiliki sikap dan perilaku yang baik dalam bekerja.

\section{Kinerja (Y)}

Adalah suatu hasil kerja yang dicapai oleh masing-masing Karyawan yang dalam pelaksanaan tugas pekerjaan yang telah ditentukan guna mewujudkan tujuan organisasi.

\section{Dimensi dan Indikator Kinerja}

Adapun indikator kinerja karyawan yang menjadi acuan dalam penelitian adalah indikator kinerja Menurut Robbins, S.P yang dapat di uraikan sebagai berikut (Robbins, 2012) :

a. Kuantitas hasil kerja

Merupakan jumlah produksi kegiatan yang dihasilkan atau diselesaikan. Pengukuran kuantitatif melibatkan perhitungan keluaran dari proses atau pelaksanaan kegiatan. Ini berkaitan dengan jumlah keluaran yang dihasilkan. Kuantitas hasil kerja dapat dilihat dari prestasi kerja yang dicapai karyawan dan pencapaian target pekerjaan karyawan.

b. Kualitas hasil kerja

Merupakan mutu yang harus dihasilkan (baik tidaknya). Pengukuran kualitatif keluaran menceminkan pengukuran "tingkat kepuasan", yaitu seberapa baik penyelesaiannya. Ini berkaitan dengan bentuk keluaran seperti keterampilan, kepuasan pelanggan, ataupun inisiatif.

c. Ketepatan waktu

Merupakan sesuai tidaknya dengan waktu yang direncanakan. Pengukuran ketepatan waktu merupakan jenis khusus dari pengukuran kuantitatif yang menentukan ketepatan waktu penyelesaian suatu kegiatan.

Selanjutnya Robbins (2012) juga menguraikan sejumlah indikator yang menjadi fokus dalam penilaian kinerja pegawai, antara lain:

a. Prestasi kerja

Ketika hasil tugas seseorang sulit ditentukan, perusahaan dapat mengevaluasi dari prilaku (hasil kerja) karyawan tersebut yang berhubungan dengan tugas.

b. Pencapaian target
Pencapaian target menjadi faktor yang tepat untuk di evaluasi, dari hasil pencapaian target dapat dilihat kemampuan karyawan dalam menyelesaikan beban pekerjaannya.

c. Keterampilan

Meliputi sekumpulan kemampuan yang bersifat teknis, antar pribadi atau berorientasi bisnis.

d. Kepuasan

Merupakan kualitas kerja yang dicapai bedasarkan syarat-syarat kesesuaian dan kesiapan karyawan.

e. Inisiatif

Merupakan semangat untuk melaksanakan tugas-tugas baru dan dalam memperbesar tanggung jawabnya.

f. Tingkat kehadiran

Tingkat kehadiran menjadi salah satu tolak ukur untuk mengetahui tingkat kedisiplinan karyawan semakin tinggi kehadirannya atau rendahnya kemangkiran maka karyawan tersebut telah memiliki disiplin kerja yang tinggi yang dapat mempengaruhi kinerja karyawan tersebut.

g. Ketaatan

Ketaatan yaitu kesadaran dan kesedia an dalam hal penyelesaian kerja.

h. On time

On time, yaitu jumlah hasil kerja yang didapat dalam suatu periode waktu yang ditentukan.

\section{Populasi dan Sampel}

Penelitian ini meneliti tentang variabel independen atau variabel bebas $(\mathrm{X})$ yang terdiri dari variabel X1 (Pelatihan), X2 (Gaya Kepemimpinan), X3 (Disiplin Kerja) dan data variabel terikat atau variabel dependen (Y) (Kinerja Karyawan). Populasi dalam penelitian ini adalah seluruh staff atau karyawan dari PT. Perkebunan Nusantara XIV (Persero) Makassar yang berjumlah sekitar 200 orang.

Untuk penentuan jumlah sampel yang akan dijadikan responden maka digunakan tekhnik Slovin. Dengan jumlah populasi 200 orang dan nilai persentase kelonggaran ketidaktelitian 5\%, yaitu :

$\mathrm{n}=\frac{\mathrm{N}}{1+\mathrm{Ne} 2}$

$\mathrm{n}:$ Jumlah Sample N : Populasi

e : Tingkat kesalahan ditetapkan $5 \%(0,05)$ 


$$
\begin{aligned}
& =\frac{200}{1+200(0.05)^{2}} \\
& =\frac{200}{1+200(0,5)} \\
& =133,33 \text { orang dibulatkan menjadi } 134 \text { orang. }
\end{aligned}
$$

Teknik pengambilan sampel dalam penelitian ini adalah menggunakan Simple Random Sampling (probability sampling). Kemudian jawaban dari para responden dijadikan masukan oleh penulis untuk menganalisis hubungan variabel-variabel di atas.responden dijadikan masukan oleh penulis untuk menganalisis hubungan variabel-variabel di atas.

Adapun sampel dalam penelitian ini meliputi karyawan pria maupun wanita dengan masa kerja bervariasi dengan patokan masa kerja minimal satu tahun. Sampel yang digunakan dalam penelitian ini mengambil responden sebanyak 134 orang

\section{Teknik Pengumpulan Data}

Untuk keperluan pengumpulan data, teknik yang digunakan adalah dengan membagikan kuisioner atau daftar pertanyaan. Sutrisno Hadi (1993) menguraikan bahwa kuesioner dalam bentuknya berdasarkan pada laporan tentang diri sendiri atau self report, atau setidak-tidaknya pada pengetahuan dan/atau keyakinan pribadi. Dengan demikian peneliti menganggap bahwa dalam menggunakan metode ini adalah subjek penelitian dianggap sebagai orang yang paling tahu tentang dirinya dan pernyataan subjek yang diberikan adalah benar dan dapat dipercaya.

\section{HASIL DAN PEMBAHASAN}

\section{Uji Instrumen Penelitian \\ 1. Uji Reliabilitas}

Untuk mengetahui apakah indikator atau kuesioner yang digunakan dapat dipercaya atau handal sebagai alat ukur variabel, maka digunakan uji reliabilitas . (Arikunto, 2008) mengemukakan bahwa reliabilitas suatu indikator atau kuesioner dapat dilihat dari nilai Cronbach's Alpha $(\alpha)$, dimana apabila nilai cronbach's alpha $(\alpha)$ lebih besar $(>) 0,60$ maka indikator atau kuesioner dianggap reliabel, sedangkan jika nilai Cronbach's Alpha $(\alpha)$ lebih kecil $(<)$ 0,60 maka indikator atau kuesioner dianggap tidak realibel

\begin{tabular}{|c|c|}
\hline Cronbach's Alpha & $\mathrm{N}$ of Items \\
\hline, 926 & 17 \\
\hline
\end{tabular}

\section{Tabel 1. Hasil Uji Reabilitas Variabel Pelatihan (X1)}

Reliability Statistics

Dari 17 pernyataan kuesioner yang disebarkan kepada 134 responden untuk variabel Pelatihan $\left(\mathrm{X}_{1}\right)$, diperoleh nilai Cronbach's Alpha sebesar 0,9261. Angka ini berada di atas 0,60. Dengan demikian berarti bahwa item pernyataan untuk semua variabel $\mathrm{X}_{1}$ dinyatakan reliabel.

\section{Tabel 2. Hasil Uji Reabilitas Variabel Gaya Kepemimpinan (X2)}

\section{Reliability Statistics}

\begin{tabular}{rc}
\hline Cronbach's Alpha & N of Items \\
\hline, 938 & $\underline{10}$
\end{tabular}

Sumber : Data diolah dengan SPSS 24

Dari 10 pernyataan kuesioner yang disebarkan kepada 134 responden untuk variabel Gaya Kepemimpinan $\left(\mathrm{X}_{2}\right)$, diperoleh nilai Cronbach's Alpha sebesar 0,937. Angka ini berada di atas 0,60 . Ini berarti bahwa semua item pernyataan variabel $\mathrm{X}_{2}$ dinyatakan reliabel.

\section{Tabel 3. Hasil Uji Reabilitas} Variabel Disiplin Kerja (X3)

\section{Reliability Statistics}

\begin{tabular}{cc}
\hline Cronbach's Alpha & $\frac{\mathrm{N} \text { of Items }}{\underline{17}}$
\end{tabular}

Sumber : Data diolah dengan SPSS 24

Dari kuesioner yang disebarkan kepada 134 responden dengan 17 pernyataan untuk variabel Disiplin Kerja $\left(\mathrm{X}_{3}\right)$, diperoleh nilai Cronbach's Alpha sebesar 0,929. Angka ini berada di atas 0,60. Ini berarti bahwa item pernyataan untuk semua variabel $\mathrm{X}_{3}$ dinyatakan reliabel.

\section{Tabel 4. Hasil Uji Reabilitas Variabel Kinerja} Karyawan (Y)

\section{Reliability Statistics}

Cronbach's Alpha $\quad$ N of Items




$914 \quad \underline{16}$

Sumber : Data diolah dengan SPSS 24

Dari kuesioner yang disebarkan kepada 134 responden dengan 16 item pernyataan untuk variabel Kinerja Karyawan (Y), dihasilkan nilai Cronbach's Alpha sebesar 0,914 Angka ini berada di atas 0,60. Dengan demikian berarti bahwa item pernyataan untuk semua variabel $\mathrm{Y}$ dinyatakan reliabel.Karena $\mathrm{r}$ alpha (Cronbach's Alpha) positif dan $\mathrm{r}$ alpha $>0,60$, semua variabel reliabel sehingga kuesioner dapat dikatakan memenuhi konsep reliabilitas.

\section{Uji Normalitas}

Bertujuan untuk menguji apakah dalam model regresi yang digunakan variabel residu memiliki distribusi normal atau tidak. Asumsi yang digunakan adalah jika nilai sig (signifikansi) > 0,05 maka data dianggap normal, sebaliknya jika nilai sig (signifikansi) yang dihasilkan < 0,05 maka data dianggap tidak berdistribusi normal.

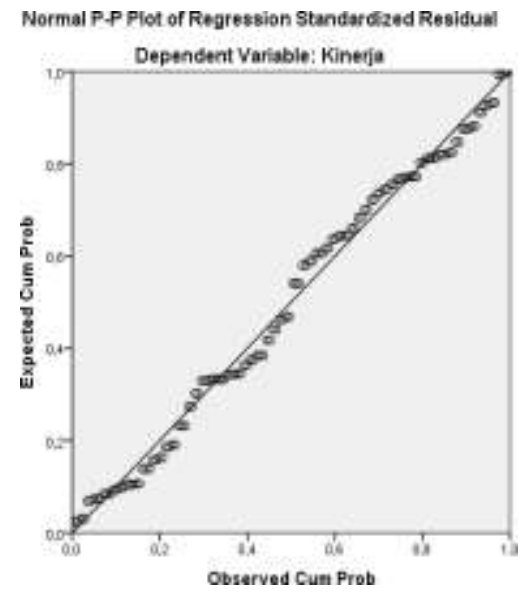

Sumber : Data diolah dengan SPSS 24

Gambar 1 : Normal P-Plot Of

Regresion Standardized Residual

Dari grafik pada gambar 1. diatas terlihat bahwa data (titik-titik) regresi menyebar disekitar garis diagonal serta penyebarannya mengikuti arah garis diagonal, ini menandakan bahwa model regresi layak digunakan.

\section{Uji Multikolinearitas}

Uji asumsi multikolinearitas dimaksudkan untuk menguji apakah dalam model regresi ditemukan adanya korelasi antar variabel independen. Untuk mendeteksi ada tidaknya gejala multikolinearitas maka dilakukan dengan melihat nilai Tolerance dan nilai Variance Inflation Factor (VIF), dalam model.

Jika nilai Tolerance lebih besar dari 0,10 maka artinya tidak terjadi multikolinearitas dalam model regresi, sedangkan jika nilai jika nilai Tolerance lebih kecil dari 0,10 maka artinya terjadi multikolinearitas dalam model regresi.

Terjadi atau tidaknya multikolineriatas dalam model regresi juga bisa dilihat dari nilai Variance Inflation Factor( VIF) lebih kecil dari 10,00 maka tidak terjadi multikolinearitas, dan sebaliknya jika nilai VIF lebih besar dari 10,00 maka terjadi multikolinearitas dalam model regresi.

Tabel 5

Hasil Uji Multikolinearitas

\begin{tabular}{crrr}
\hline Model & \multicolumn{3}{c}{ Collinearity Statistics } \\
\cline { 3 - 4 } & & Tolerance & \multicolumn{1}{c}{ VIF } \\
\hline \multirow{3}{*}{1} & $\mathrm{X} 1$ & .412 & 2.0365 \\
\cline { 2 - 4 } & $\mathrm{X} 2$ & .292 & 3.355 \\
\cline { 2 - 4 } & $\mathrm{X} 3$ & .531 & 1.8524 \\
\hline
\end{tabular}

a. Dependent Variable: Kinerja Karyawan

Sumber : Data diolah dengan SPSS 24

Dari hasil pengujian multikolinearitas pada tabel diatas, untuk variabel Pelatihan (X1) didapatkan nilai Tolerance $>0,10$ yaitu sebesar 0,412 dan nilai VIF $<10,00$. yaitu sebesar 2,0365, dengan demikian bisa disimpulkan bahwa tidak terjadi multikolinearitas. Demikian juga dengan dan hasil dari Tolerance untuk variabel Gaya Kepemimpinan adalah sebesar 0,292 atau >0,10 dan untuk nilai VIF lebih kecil dari 0,10 yaitu sebesar 3,355 , jadi bisa bahwa disimpulkan bahwa untuk Variabel Gaya Kepemimpinan tidak terjadi multikolinearitas. Untuk variabel Kedisiplinan nilai Tolerance yang dihasilkan sebesar 0,531 atau >0,10 dan nilai VIF sebesar 1,8524 atau < 10, Maka tidak terjadi adanya multikolinearitas. 




\section{Korelasi Product Momen}

1. Uji Koefisien Korelasi

Untuk menguji ada tidaknya pengaruh atau hubungan timbal balik dari dua variabel atau

\begin{tabular}{|c|c|c|c|c|c|}
\hline $\begin{array}{l}\text { TrKoetissen } \\
\text { Rernlan }\end{array}$ & $\begin{array}{l}\text { Poinon } \\
\text { Contiatian }\end{array}$ & 1 & $-1289^{\circ *}$ & 91 & $98^{\circ *}$ \\
\hline \multirow[t]{3}{*}{$\mathrm{xt}$} & Sie 2 sailat & & 50 & $\operatorname{sen}$ & 260 \\
\hline & $\mathrm{N}$ & 134 & 134 & 134 & 14 \\
\hline & $\begin{array}{l}\text { Pearson } \\
\text { Coctelatica }\end{array}$ & $-329^{40}$ & 1 & $m s^{\circ}$ & $-310^{* *}$ \\
\hline \multirow[t]{2}{*}{$x=$} & Sir (2-silas) & 000 & & 000 & oso \\
\hline & st & 134 & 134 & 134 & 14 \\
\hline \multirow[t]{3}{*}{$\mathrm{x} 3$} & Sis (Eexided) & 900 & 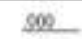 & & 200 \\
\hline & $\mathrm{N}$ & 134 & 13 & 134 & 134 \\
\hline & $\begin{array}{l}\text { Persson } \\
\text { Coentlation }\end{array}$ & $998^{\circ "}$ & $-816^{* 0}$ & 973 & $t$ \\
\hline \multirow[t]{2}{*}{ Y } & 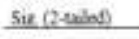 & 000 & 800 & 000 & \\
\hline & s & 134 & 134 & 134 & 14 \\
\hline
\end{tabular}

Dari tabel 6 di atas memperlihatkan hasil korelasi semua variabel independen memiliki signifikan kurang dari 0,05. Dengan demikian bisa disimpulkan bahwa semua variabel independen memiliki korelasi dengan Kinerja Karyawan dengan tingkat nilai korelasi yang berbeda.

a. Pelatihan dengan Kinerja Karyawan, Kinerja Karyawan memiliki nilai signifikan $0,00<0,05$ dan memiliki besar hubungan 0,998, dengan demikian Pelatihan memiliki korelasi dengan Kinerja karyawan.

b. Gaya Kepemimpinan dengan Kinerja Karyawan, Gaya Kepemimpinan memiliki nilai nilai signifikan $0,00<0,05$ dengan nilai hubungan sebesar 0,816. jadi bisa disimpulkan bahwa Gaya Kepemimpinan mempunyai korelasi dengan Kinerja Karyawan.

c. Disiplin Kerja dengan Kinerja Karyawan memiliki nilai signifikan $0,00<0.05$ dan memiliki besar hubungan 0,973, ini mengindikasikan bahwa Disiplin Kerja memiliki korelasi dengan Kinerja Karyawan. Pelatihan dengan Kinerja Karyawan, Kinerja Karyawan memiliki nilai signifikan $0,00<0,05$ dan memiliki besar hubungan 0,998 , dengan demikian Pelatihan memiliki korelasi dengan Kinerja lebih maka terlebih dahulu diadakan uji korelasi. Uji Korelasi adalah suatu teknik statistik yang digunakan untuk mengukur besar kecilnya hubungan antara dua variabel dinyatakan bilangan yang disebut

Koefisien korelasi (Sugiyono,2009)

\section{Uji Koefisien Determinasi}

Untuk mengetahui besarnya sumbangan atau kontribusi dari keseluruhan variabel bebas dan pengaruhnya terhadap variabel terikat (Y) maka digunakan Koefisien determinasi berganda $\left(\mathrm{R}^{2}\right)$ sebagai tolok ukurnya, sedangkan sisanya dipengaruhi oleh variabel lain yang tidak diteliti dalam penelitian ini. Hasil uji $\mathrm{R}^{2}$ dapat diilustrasikan pada tabel berikut:

Tabel 7. Uji Koefisien Determinasi

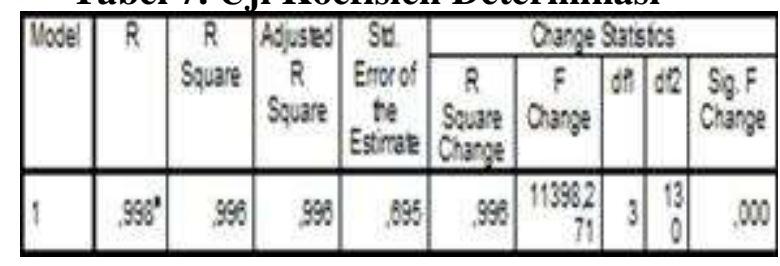

Sumber : Data diolah dengan SPSS 24

Dari ilustrasi Tabel 7 bisa tergambar bahwa koefisien determinasinya $\left(\mathrm{R}^{2}\right)$ sebesar 0,996 atau 99,6\%. Ini menunjukkan bahwa keseluruhan variabel independen yaitu Pelatihan, Gaya Kepemimpinan dan Disiplin Kerja secara simultan atau secara serempak mampu menjelaskan hubungan Kinerja Karyawan. Sedangkan sisanya sebesar $0,4 \%$ dijelaskan oleh sebab-sebab lain diluar model

\section{Uji Persamaan Regresi}

Pengujian hipotesis ini bertujuan untuk mengetahui pengaruh antara keseluruhan variabel independen (bebas) dengan variabel dependen (terikat). Sesuai hipotesis penelitian ini yang menyatakan bahwa diduga seluruh variabel independen yang meliputi Pelatihan $\left(\mathrm{X}_{1}\right)$, variabel Gaya Kepemimpinan $\left(\mathrm{X}_{2}\right)$ dan variabel Disiplin Kerja $\left(X_{3}\right)$ secara simultan mempengaruhi Kinerja Karyawan (Y). Hasil uji-F dapat dilihat pada tabel berikut ini 
Tabel 8. Uji Koefisien Regresi Secara Bersama- sama (Uji F)

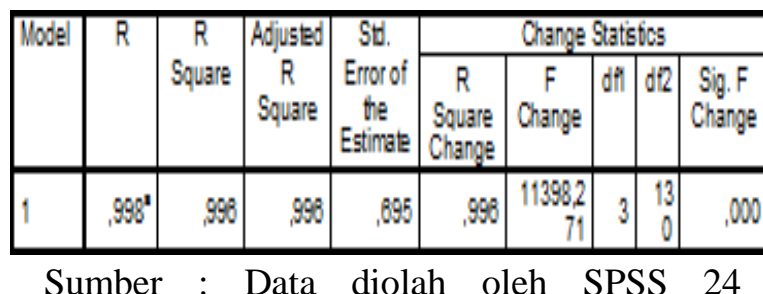

Berdasarkan hasil perhitungan yang dapat dilihat pada tabel 8 menunjukkan Uji F yang dilakukan untuk menguji pengaruh variabel bebas secara bersama-sama terhadap variabel terikatnya, hasil dari perhitungan statistik menunjukkan nilai $\mathrm{F}$ hitung = 11398,271 dengan menggunakan taraf Pvalue 0,05 , maka diperoleh nilai $\mathrm{P}$-value sebesar 0,000, dimana nilai P-value yang didapat lebih kecil dari 0,05 . Hal ini berarti bahwa hipotesis yang menyatakan bahwa pengujian secara bersama-sama, variabel Pelatihan, Gaya Kepemimpinan, Disiplin Kerja, mempunyai pengaruh positif terhadap Kinerja Karyawan.

\section{Kesimpulan dan Saran}

\section{Kesimpulan}

Berdasarkan temuan penelitian dan hasil pembahasan, maka kesimpulan yang didapat dari penelitian ini adalah:

1. Adanya pengaruh positif dan signifikan antara pelatihan terhadap kinerja karyawan PT. Perkebunan Nusantara XIV (Persero) Makassar.

2. Adanya pengaruh positif dan signifikan antara gaya kepemimpinan terhadap kinerja karyawan PT. Perkebunan Nusantara XIV (Persero) Makassar.

3. Adanya pengaruh positif dan signifikan antara disiplin kerja terhadap kinerja karyawan PT. Perkebunan Nusantara XIV (Persero) Makassar.

4. Dari ketiga variabel penelitian pelatihan, gaya kepemimpinan dan disiplin kerja yang termasuk variabel paling dominan terhadap kinerja karyawan PT. Perkebunan Nusantara XIV (Persero)
Makassar adalah gaya kepemimpinan.

\section{Saran}

Hasil dari penelitian ini membuahkan saran sebagai berikut:

1. Peningkatan kinerja karyawan tidak akan berhasil tanpa kemampuan/skill yang memadai dari karyawan tersebut. Upaya peningkatan kualitas karyawan melalui pemberian pelatihan tentunya tidak akan berdampak maksimal tanpa melibatkan instruktur yang qualified baik dari segi pendidikan dan pengalaman sang instruktur, penguasaan materi yang baik, dst. Begitupun peserta pelatihan harus betul-betul bersemangat dalam mengikuti materi sehingga materi yang disampaikan bisa diserap. Materi yang disampaikan harus sesuai dengan tujuan pelatihan, metode penyampaian materi harus tepat dan disesuaikan dengan komponen peserta pelatihan, sehingga dengan demikian pelatihan benar-benar bisa berhasil meningkatkan keterampilan peserta pelatihan dalam hal ini karyawan yang pada ujung-ujungnya akan bermuara pada peningkatan kinerja mereka.

2. Gaya kepemimpinan merupakan salah satu stimulus karyawan yang sangat berperan terhadap baik buruknya kinerja karyawan. Penerapan gaya kepemimpinan yang tepat yang bisa mempengaruhi karyawan untuk berbuat maksimal terhadap organisasi/perusahaan tentunya merupakan keniscayaan yang harus diperhatikan dengan seksama oleh seorang pemimpin. Karyawan akan melihat pemimpin sebagai panutan dan contoh yag patut diteladani, oleh karenanya seorang pemimpin harus bisa memotivasi, memiliki kecerdasan dan bakat yang membuat bawahannya selalu termotivasi untuk meningkatkan kualitas diri, untuk selalu kreatif, inovatif dan memiliki empati terhadap sesama, baik indididu didalam organisasi maupun yang diluar organisasi. 
3. Kinerja karyawan juga bisa meningkat jika ditunjang oleh disiplin kerja yang baik dari karyawan. Perilaku disiplin kerja ini bisa dibentuk menjadi budaya kerja jika dari awal karyawan dibebankan pekerjaan yang sesuai demgan potensi dan kemampuannya. Karyawan juga harus dibiasakan hadir tepat waktuditempat kerja dan pulang sesuai dengan waktu yang telah ditetapkan. Karyawan yang disiplin kerjanya bagus juga selalu memiliki tingkat kewaspadaan dan ketelitiannnya dalam melaksanakan pekerjaan dan tanggung jawabnya. Karyawan yang disiplin juga terbiasa menjaga dengan baik aset-aset kantor, mempunyai etika dan perilaku yang baik dalam berhubungan dengan rekan kerja dan atasannya sehingga tercipta suasana saling menghargai ditempat kerja, dengan demikian tercipta suasana kerja yang kondusif.

\section{DAFTAR RUJUKAN}

Achmad Sanusi. \& M. Sobry Sutikno. 2009. Kepemimpinan Sekarang dan Masa Depan Dalam Membentuk Budaya Organisasi Yang Efektif . Jakarta: Prospect.

Arep, Ishak \& Hendri, Tanjung. 2002. Manajemen Sumber Daya Manusia. Jakarta: BP Universitas Trisakti.

Armstrong, Michael. 2009. Armstrong's Handbook of Human Resource Management Practice. London : Kogan Page.

Djarwanto. 1994. Pokok-pokok Metode Riset dan Bimbingan Teknis Penulisan Skripsi. Yogyakarta : Andi

George R. Terry. 2000. Prinsip-Prinsip Manajemen (Edisi Bahasa Indonesia).: Bandung : PT. Bumi Aksara.
Ghozali, Imam. 2006. Aplikasi Analisis Multivariate dengan Program SPSS. Semarang : Badan Penerbit Universitas Diponegoro.

Hersey. 2004. Kunci Sukses Pemimpin Situasional. Jakarta : Delaprasata .

Hasibuan, Malayu S.P. 2006. Manajemen Dasar, Pengertian, dan. Masalah, Edisi Revisi. Jakarta : Bumi Aksara.

Ivancevich, J.M., Konopaske, R., dan Matteson M.T. 2006. Perilaku dan Manajemen Organisasi. Jilid 1 dan 2. Edisi ketujuh. Jakarta : Erlangga.

Kartono, Kartini. 2005. Pemimpin dan Kepemimpinan. Jakarta : Rajawali.

Kotter, JP \& J.L. Heskett. 1997. Corporate Culture and Performance. Jakarta : PT. Prenhallindo.

Kreitner, Robert dan Kinicki, Angelo. 2003. Perilaku Organisasi. Edisi pertama. Buku 1. Jakarta : Salemba Empat.

(2008). Organizational

Behaviour 8th edition. New York : McGraw Hill International Edition.

Martoyo, S. 2000. Manajemen Sumber Daya Manusia. Yogjakarta : BPFE.

Moejiono, Imam. 2002. Kepemimpinan dan Keorganisasian. Yogyakarta : UII Press.

Nawawi, Hadari. 2006. Kepemimpinan yang Efektif. Yogyakarta : Gajah Mada University Press. 2003.

Kepemimpinan Mengefektifkan Organisasi. Yogyakarta : Gajah Mada University Press.

Abdul Aziz . 1998 . Pengaruh Motivasi, Disiplin dan Ethos Kerja Terhadap Produktivitas Karyawan Pada PT. Perkebunan Nusantara VII Lampung.(1) 1-7.

Syafrizal Helmi. 2003. Pengaruh Pelatihan dan Pengembangan serta Prestasi Kerja terhadap Pengembangan Karir Pada PT. Perkebunan Nusantara III ( Persero ) Medan. (1) 1-15 